\title{
BORON NUTRITION AND YIELD OF ALFALFA CULTIVAR CRIOULA IN RELATION TO BORON SUPPLY
}

\author{
Anacleto Ranulfo dos Santos; Waldssimiler Teixeira de Mattos²; Ana Aparecida da Silva \\ Almeida $^{3}$; Francisco Antonio Monteiro ${ }^{4 *}$; Beatriz Dias Corrêa ${ }^{5}$; Umesh C. Gupta ${ }^{6}$ \\ ${ }^{1}$ UFBA/AGR - Depto. de Solos, C.P. 82 - 44380-000 - Cruz das Almas, BA - Brasil. \\ ${ }^{2}$ Instituto de Zootecnia - R. Heitor Penteado, 56 - 13460-000 - Nova Odessa, SP - Brasil \\ ${ }^{3}$ Universidade de Taubaté - Depto. de Biologia, Av. Tiradentes, 500 - 12030-180 - Taubaté, SP - Brasil. \\ ${ }_{5}^{4}$ USP/ESALQ - Depto. de Solos e Nutrição de Plantas, C.P. 9 - 13418-900 - Piracicaba, SP - Brasil. \\ ${ }^{5}$ R. Campos Salles, 1123 - 13416-310 - Piracicaba, SP - Brasil. \\ ${ }^{6}$ Agriculture and Agri-Food Canada, Crops and Livestock Centre PE, Charlottetown - Canada. \\ *Corresponding author <famontei@esalq.usp.br>
}

\begin{abstract}
Alfalfa cultivar Crioula (Medicago sativa cv. Crioula) is grown in South Brazil and only a few studies on the plants' boron requirement are available. A greenhouse experiment was carried out with alfalfa to measure boron acquisition, production and distribution in the plant; data on critical level and production potentials were recorded. Plants were grown in ground quartz added with $1 \mathrm{~L}$ of solution, with the following boron rates: $0,0.0625,0.125,0.25,0.50,1.00$, and $2.00 \mathrm{mg} \mathrm{L}^{-1}$. Plants were harvested at 46 days of growth. Forage dry mass was increased by boron supply and dry matter accumulation was considerably low in control. Boron concentration in the leaves was higher than in the stems or roots. Boron utilization from the external solution reached $90 \%$ at $0.0625 \mathrm{mg} \mathrm{L}^{-1}$ and sharply decreased with further increasing boron rates. Boron concentration and content in the leaves and in plant tops were at maximum when applied boron was between 1.5 and $1.6 \mathrm{mg} \mathrm{L}^{-1}$. Critical levels of boron in plant were $61 \mathrm{mg} \mathrm{kg}^{-1}$ in the leaves and $39 \mathrm{mg} \mathrm{kg}^{-1}$ in plant tops for this cultivar of alfalfa.
\end{abstract}

Key words: Lucerne, Medicago sativa, plant nutrition, micronutrient, critical level

\section{NUTRIÇÃO EM BORO E PRODUÇÃO DE ALFAFA CULTIVAR CRIOULA EM FUNÇÃO DO SUPRIMENTO DE BORO}

\begin{abstract}
RESUMO: O cultivar Crioula de alfafa (Medicago sativa cv. Crioula) é utilizado no Sul do Brasil e existem poucos estudos referentes a sua exigência em boro. Foi conduzido um experimento com alfafa cultivada no inverno, com o objetivo de avaliar a quantidade de boro absorvido pelas plantas, o efeito de doses de boro na produção de massa seca, a distribuição do boro nas plantas e obter informações relacionadas à diagnose de boro nessa forrageira. As doses de 0; 0,0625; 0,125; 0,25; 0,50; 1,00 e 2,00 $\mathrm{mg} \mathrm{L}^{-1}$ foram aplicadas no substrato, colocando-se $1 \mathrm{~L}$ de solução nutritiva em cada recipiente. As plantas foram cortadas aos 46 dias após o transplante. A massa seca da forrageira foi influenciada pelas doses de boro e foi insignificante quando a solução nutritiva apresentava a mais baixa concentração de boro. A concentração de boro nas folhas foi mais elevada que nas hastes e nas raízes. A utilização de boro da solução atingiu $90 \%$ na dose de $0,0625 \mathrm{mg} \mathrm{L}^{-1} \mathrm{e}$ decresceu acentuadamente com o incremento das doses de boro. A concentração e o conteúdo de boro nas folhas e na parte aérea da planta foram mais elevados quando o boro se encontrava na solução nutritiva entre 1,5 e 1,6 $\mathrm{mg} \mathrm{L}^{-1}$. O nível crítico de boro foi de $61 \mathrm{mg} \mathrm{kg}^{-1}$ nas folhas e $39 \mathrm{mg} \mathrm{kg}^{-1}$ na planta para este cultivar de alfafa.
\end{abstract}

Palavras-chave: Medicago sativa, nutrição de plantas, micronutriente, nível crítico

\section{INTRODUCTION}

Alfalfa (Medicago sativa L.) is one of the important forage crops in South Brazil, where beef and dairy industries are common (Nuernberg, 1986). It has been cultivated since the nineteenth century for its high quality forage and diversity for animal feeding (Botrel \& Alvim, 1994).

Boron is one of the important micronutrients required for good plant production, and its deficiency normally reduces the size of the root system and leads to meristematic tissue death. Gupta (1979a) pointed out the need for continuous boron supply for good plant growth. In general, all dicots require higher amount of boron than monocots, and usually leaf boron concentration in plants ranges from 10 to $100 \mathrm{mg} \mathrm{kg}^{-1}$ (Dechen et al., 1991).

Sherrel \& Toxopeus (1978) and Gupta (1984) showed increases in alfalfa dry matter yield when boron was supplied to the substrate. Haddad \& Kaldor (1982) 
reported beneficial effects of boron application to soils derived from sandstone and granite, but not for some alluvial or basic rock derived soils.

Otsubo (1993) grew alfalfa cultivar Crioula in a soil with medium hot water-extractable boron $(0.48 \mathrm{mg}$ $\mathrm{kg}^{-1}$ ) at rates ranging from 0 to $4 \mathrm{mg} \mathrm{kg}^{-1}$. Boron availability in that soil met plant requirement and no change in forage dry matter was found.

There are few studies available on the B requirement of alfalfa cultivar Crioula which is most commonly grown in Brazil. The objective of this investigation was to determine: I. the boron acquisition by this alfalfa cultivar; II. the boron need for improving alfalfa production; III. the boron distribution in the plants; IV. the best correlation of boron concentration with plant dry matter yield; and V. the critical level of boron in leaf tissue. To precisely control the level of $\mathrm{B}$ in growth medium, culture experiment was conducted.

\section{MATERIAL AND METHODS}

A greenhouse experiment was conducted in plastic pots containing $5 \mathrm{~kg}$ ground quartz. Alfalfa (Medicago sativa L. cv. Crioula) was used for this study with seven rates of boron $(0 ; 0.0625 ; 0.125 ; 0.25 ; 0.50 ; 1.00$; and $2.00 \mathrm{mg} \mathrm{L}^{-1}$ ) in the nutrient solution. Seeds of alfalfa were germinated in plastic tray containing washed sand and seedlings were transferred to pots when they were $5 \mathrm{~cm}$ tall. Five plants were kept in each pot throughout the experiment. The nutrient solution proposed by Sarruge (1975) was modified to meet the desired boron rates using boric acid. Each pot received $1 \mathrm{~L}$ of nutrient solution and the loss in volume was compensated each morning. A nutrient solution corresponding to one-fourth strength of each boron rate was first supplied to the plants and replaced to supply the boron rates four days after, and again 18 and 32 days after starting the experiment.

Plants were harvested at the pre-flowering stage, 46 days after transplanting. At that time, leaves were separated from the stems and the roots were taken off the substrate. All plant parts were dried in a forced air-circulating oven at $65^{\circ} \mathrm{C}$, weighed and ground to pass a 2 mm sieve. Forage dry matter yield was obtained by adding up the weight of leaves and stems.

Boron was determined in leaves, stems and roots samples ashed in an oven at $450^{\circ} \mathrm{C}$; the azomethine colorimetric method was used for determination (Gupta, 1979b). Ratio of boron concentrations in the three plant parts was calculated. Total concentration of boron in plant tops was calculated using the boron concentrations and forage dry matter in the two plant parts. Boron utilization was calculated by dividing the total boron contents in plants by the total boron supplied through each nutrient solution.
A randomized complete block experimental design with four replications was used. Statistical analysis were performed by analysis of variance and regression analysis through linear and non-linear models (SAS Institute, 1989). When appropriated, means were compared by the Tukey test $(\alpha=0.05)$. Data on forage dry matter yield was related to plant boron concentration to obtain the critical level of this nutrient.

\section{RESULTS AND DISCUSSION}

Forage yield was affected by concentration of boron in the nutrient solution (Figure 1). When boron was absent or present in very low concentrations (less than $0.1 \mathrm{mg} \mathrm{L}^{-1}$ ) in the nutrient solution, alfalfa did not grow and forage dry matter was negligible. Forage dry matter increased slightly as boron in the solution increased from 0.025 to $2 \mathrm{mg} \mathrm{L}^{-1}$, and this upper limit is much higher than the $0.5 \mathrm{mg} \mathrm{L}^{-1}$ ordinarily used in the Sarruge's nutrient solution, what confirms that this legume has high boron requirement (Mengel \& Kirkby, 2001).

Separating leaves and stems from plant tops enabled to observe that, in both plant parts, dry matter was increased by boron supply. The models to which data were fitted are: $\mathrm{Y}=4.4561\left[1-10^{(-10.9689 \mathrm{X})}\right]\left(\mathrm{R}^{2}=0.98\right)$ for the leaf, and $\mathrm{Y}=4.3131\left[1-10^{(-11.5141 \mathrm{X})}\right]\left(\mathrm{R}^{2}=0.96\right)$ for the stem dry matter. Both leaf and stem dry matter changed in similar amounts as boron rates increased. Such variations was not observed for sunflower (Helianthus annus L.), which presented bigger increase in stem than in leaf dry matter as boron rate increased from 0.1 to $0.5 \mathrm{mg} \mathrm{L}^{-1}$ (Capoani, 2001). Since alfalfa leaf is preferably eaten by animals and has better nutritive value than stems, these observations are meaningful.

Boron content in leaves was higher than in the whole plant tops (Figure 2). The highest boron concentration in leaves (109 $\left.\mathrm{mg} \mathrm{kg}^{-1}\right)$ was found when boron in

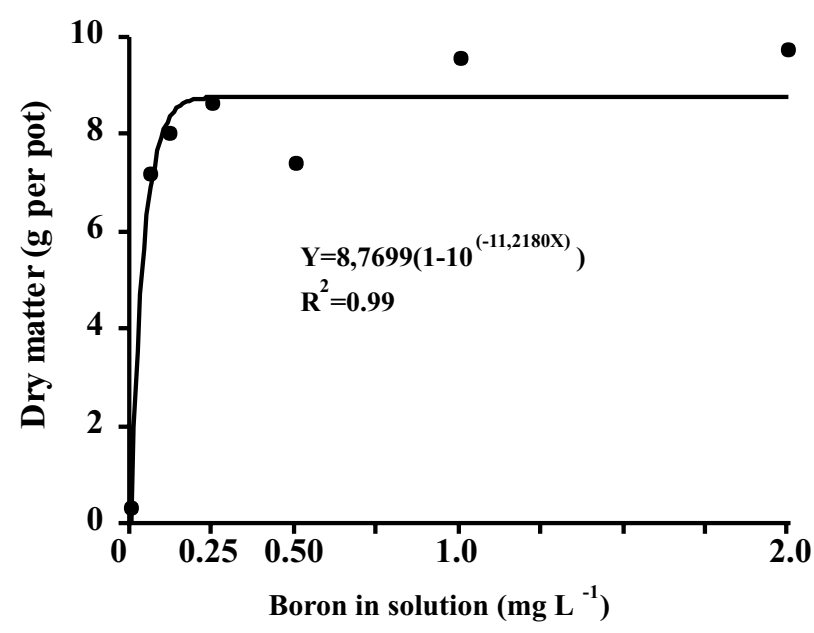

Figure 1 - Forage dry matter of alfalfa cultivar Crioula as related to boron rates in the nutrient solution. 
the nutrient solution was $1.62 \mathrm{mg} \mathrm{L}^{-1}$, whereas the maximum for the plant tops $\left(66 \mathrm{mg} \mathrm{kg}^{-1}\right)$ occurred at $1.53 \mathrm{mg} \mathrm{L}^{-1}$ of nutrient solution. Boron concentrations in stems or roots were poorly related $\left(R^{2}=0.44\right)$ to boron supply. These results agree with those of Smith (1970) and Rominger et al. (1975), who found higher boron concentrations in plant tops than in stems or roots of alfalfa.

In this study, boron concentrations in plant tops ranged from 11 to $66 \mathrm{mg} \mathrm{kg}^{-1}$. Otsubo (1993) also reported boron concentrations in plant tops of alfalfa from 43 to 108 $\mathrm{mg} \mathrm{kg}^{-1}$. Cihacek (1994) recommend boron concentration ranging from 30 to $80 \mathrm{mg} \mathrm{kg}^{-1}$ for good alfalfa growth.

The ratios of leaves-to-roots and leaves-to-stems boron concentrations, which demonstrate the plant part that more accumulates boron as related to supply, increased from 1.6 to 5.3 and 1.8 to 5.5, respectively, with increasing boron rates (Figure 3). Boron uptake depends

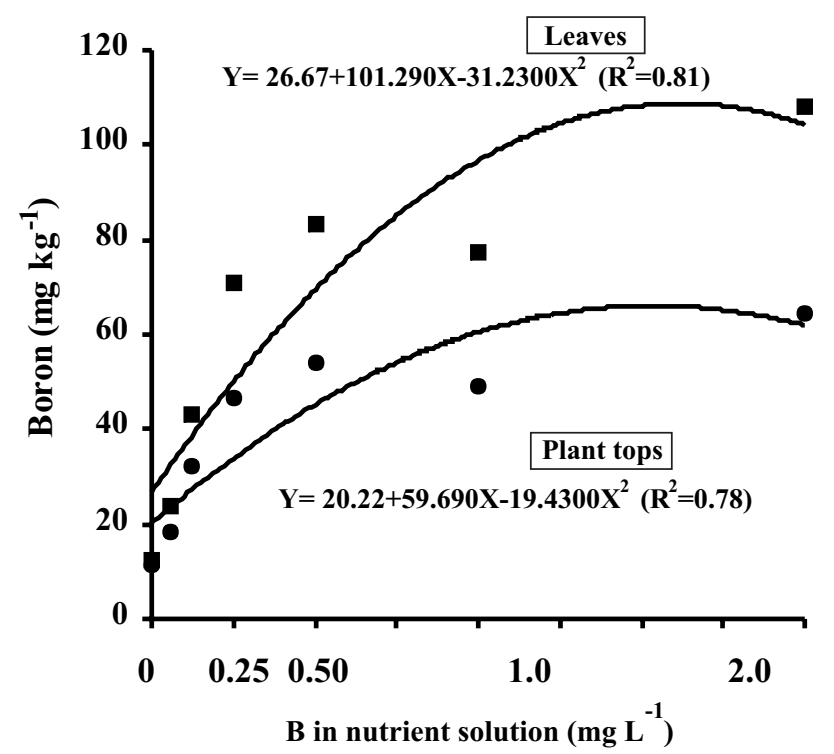

Figure 2 - Boron concentration in plant top and in the leaves of alfalfa cultivar Crioula as related to boron rates in the nutrient solution. on the concentration of boric acid in the external solution, as demonstrated by Oertli \& Grigurevic (1975) with barley, and by Brown \& Hu (1994) with sunflower (Helianthus annus L.), squash (Cucurbita pepo L.) and tobacco (Nicotiana tabacum L.). Higher concentration of boron in leaves than in stems or roots was also cited by Mengel \& Kirkby (2001). This preferential boron location in leaves than in stems or roots is related to the loss of water from the leaves through the transpiration process (Marschner, 1995).

Boron recovery from the external medium changed with boron rates (Figure 4). At boron rate of $0.0625 \mathrm{mg} \mathrm{L}^{-1}$, plants took $90 \%$ of the boron supplied during the entire experiment (from the four solutions supplied). This high percentage of boron utilization is certainly due to the passive diffusion of boron into the plants with the formation of boron complexes, which in turn allows further absorption of this nutrient from the external medium (Hu \& Brown, 1997). As boron rates increased, the percentage boron utilization sharply decreased to 16.7 and $11.1 \%$, at boron rates of 1.0 and $2.0 \mathrm{mg} \mathrm{L}^{-1}$, respectively. Such kind of plant control (not taken at high part of boron supplied) of boron uptake is in agreement with Mengel \& Kirkby (2001), who pointed out that boron transport across plant membranes by passive mechanism is doubtful.

Boron content in alfalfa plant tops increased as concentration of boron increased in the nutrient solution (Figure 5). The maximum amount of boron in the plant tops (647 $\mu$ g per pot) was found when boron in the nutrient solution was at $1.57 \mathrm{mg} \mathrm{L}^{-1}$. This boron concentration in the solution is very close to 1.62 and $1.53 \mathrm{mg} \mathrm{L}^{-1}$ observed for maximum boron concentration in the plant tissue. Since forage dry matter yield did not increase when boron was higher than $0.5 \mathrm{mg} \mathrm{L}^{-1}$ in the nutrient solution, these very close values for boron concentration in the solution are related to the accumulation of boron in the top of alfalfa plants.

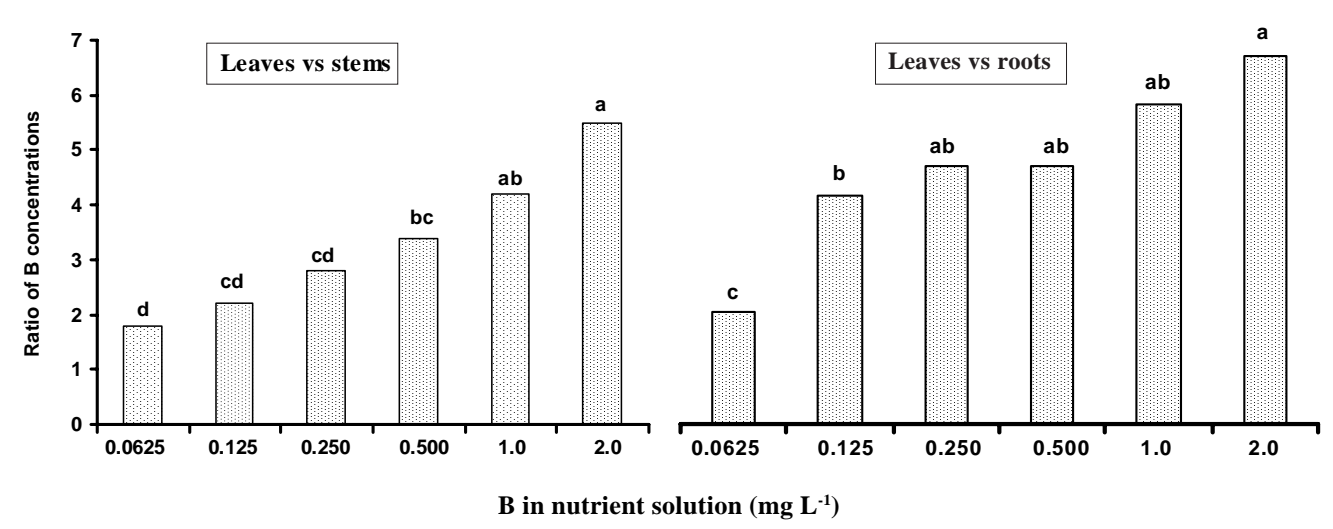

Figure 3 - Ratio of boron concentrations in leaves vs stems and leaves vs roots of alfalfa cultivar Crioula, as related to boron rates in the nutrient solution. 
Alfalfa roots accumulated less boron than plant tops. Even at the highest boron rate in the nutrient solution, boron in roots did not reach $100 \mu \mathrm{g}$ per pot, which was the lowest value for plant tops. The ratio between boron content in plant tops and roots increased as more boron was supplied in the nutrient solution. These findings denote a preferential accumulation of boron in plant tops than in roots of alfalfa.

There was a distinct difference in boron content in leaves, stems and roots of alfalfa. At the lowest rate of boron in the solution, roots and stems had each about one-fourth of the total boron content in plants, and leaves contained about half that much. With the increasing rates of boron in the solution, the total boron content in alfalfa roots and stems decreased to about $13 \%$ each, whereas in leaves, increased $74 \%$ of the total boron in the plants. Increased boron supply creates a steep gradient in boron content in plant parts, which can even promote boron toxicity in cases of high boron supply (Marschner, 1995).

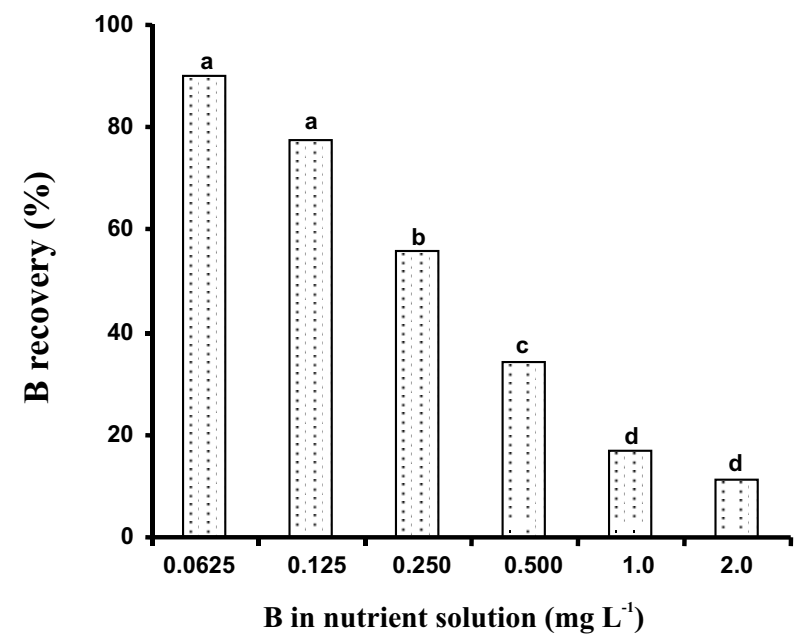

Figure 4 - Percentage boron recovery from the nutrient solution by the alfalfa cultivar Crioula.

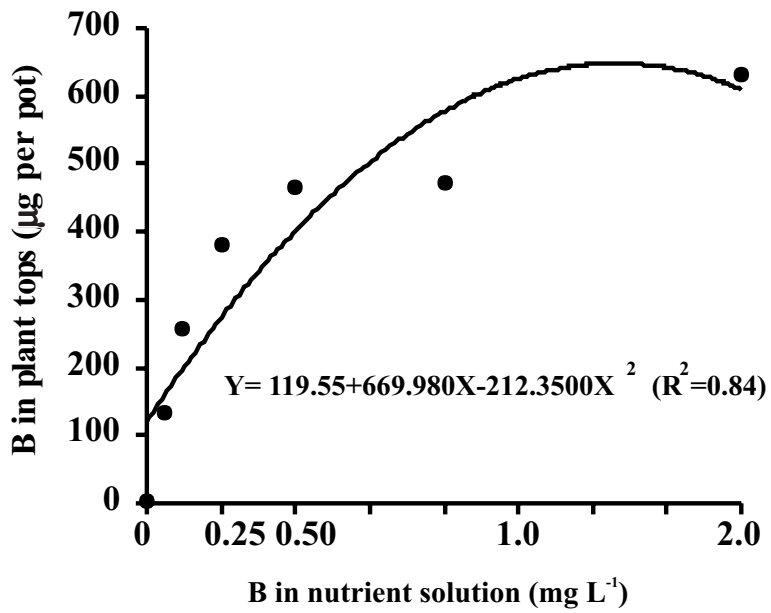

Figure 5 - Boron content in plant tops of alfalfa cultivar Crioula as related to boron rates in the nutrient solution.
Boron concentration in leaves as well as in plant tops were correlated to forage dry matter yield. A second-order model with a correlation coefficient of 0.85 fitted well in both cases (Figures 6 and 7). By using the $90 \%$ of maximum forage dry matter, the critical levels of boron in plant tissue were found to be $61 \mathrm{mg} \mathrm{kg}^{-1}$ in the leaves and $39 \mathrm{mg} \mathrm{kg}^{-1}$ in the plant tops.

Compiling results from the greenhouse and field experiments published during 15 years, Melsted et al. (1969) suggested the concentration of $30 \mathrm{mg} \mathrm{kg}^{-1}$ in plant tops as critical level for boron in alfalfa. Haddad \& Kaldor (1982) pointed out $25 \mathrm{mg} \mathrm{kg}^{-1}$ as the critical concentration for alfalfa, whereas Martin \& Matocha (1973) reported a range of 20 to $30 \mathrm{mg} \mathrm{kg}^{-1}$ in different plant parts of alfalfa. The critical level of boron obtained in this experiment for the alfalfa cultivar Crioula was higher than those recommended by other authors as average for alfalfa.

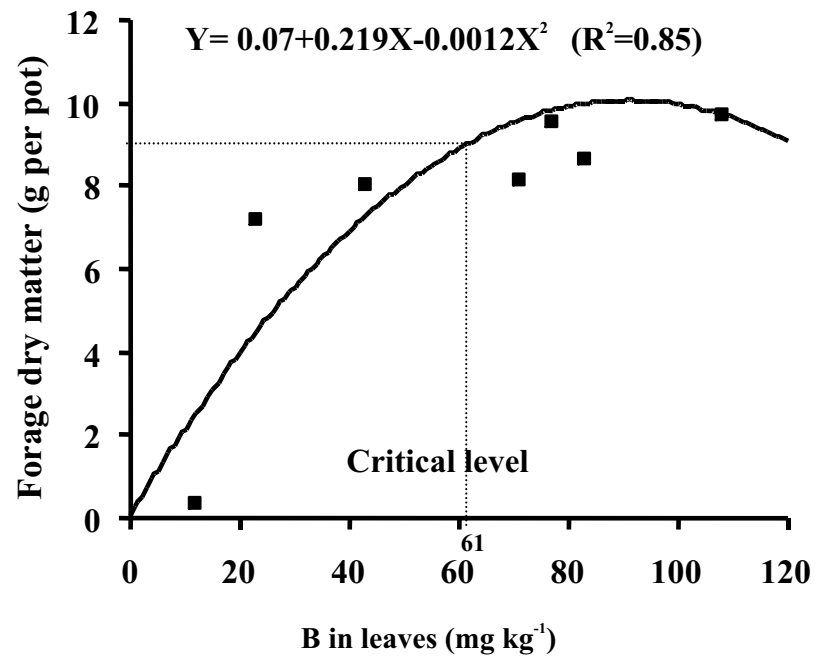

Figure 6 - Relationship between boron concentration in leaves and forage dry matter of alfalfa cultivar Crioula.

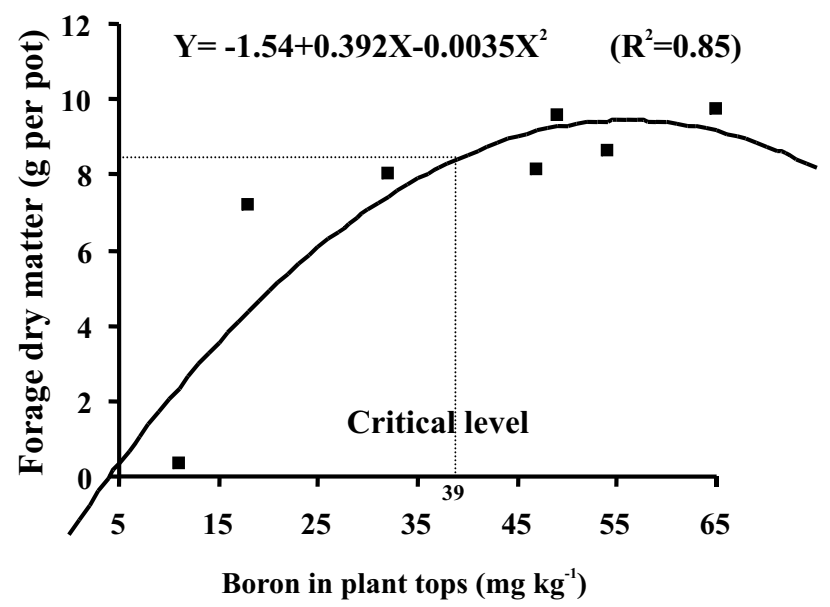

Figure 7 - Relationship between boron concentration in plant tops and forage dry matter of alfalfa cultivar Crioula. 


\section{CONCLUSIONS}

Boron supply in the nutrient solution greatly affected forage dry matter yield of alfalfa cultivar Crioula. Forage dry matter was low at boron rates below $0.1 \mathrm{mg} \mathrm{L}^{-1}$. Concentration of boron in leaves was much higher than in stems and roots. At very low boron supply, almost all boron was taken up by the plants and boron acquisition sharply decreased with increasing boron rates. Boron concentrations in leaves or leaves + stems were highly correlated with forage dry matter yield. The critical levels of boron in the cultivar Crioula of alfalfa were $61 \mathrm{mg} \mathrm{kg}^{-1}$ in the leaves and $39 \mathrm{mg} \mathrm{kg}^{-1}$ in the plant tops.

\section{ACKNOWLEDGMENTS}

To the Coordenação de Aperfeiçoamento de Pessoal de Nível Superior (CAPES), to Conselho Nacional de Desenvolvimento Científico e Tecnológico (CNPq) and to Fundação de Amparo a Pesquisa do Estado de São Paulo (FAPESP) for the scholarships to the authors.

\section{REFERENCES}

BOTREL, M.A.; ALVIM, M.J. Avaliações preliminares de alfafa, na região da zona da mata de Minas Gerais. In: WORKSHOP SOBRE O POTENCIAL FORRAGEIRO DA ALFAFA (Medicago sativa L.) NOS TRÓPICOS. Juiz de Fora, 1994. Juiz de Fora: EMBRAPA, CNPGL, 1994. p.37-45.

BROWN, P.H.; HU, H. Boron uptake by sunflower, squash and cultured tobacco cells. Physiologia Plantarum, v.91, p.435-441, 1994.

CAPOANI, M.T. Níveis de cálcio e de boro na solução nutritiva para os cultivares de girassol IAC - Uruguai e Rumbossol - 91. Piracicaba: USP/ ESALQ, 2001. 60p. (Dissertação-Mestrado).

CIHACEK, L.J. Alfalfa nutrient needs and fertilization. In: WORKSHOP SOBRE O POTENCIAL FORRAGEIRO DA ALFAFA (Medicago sativa L.) NOS TRÓPICOS. Juiz de Fora, 1994. Juiz de Fora: EMBRAPA, CNPGL, 1994. p.93-97.

DECHEN, A.R.; HAAG, H.P.; CARMELLO, Q.A.C. Funções dos micronutrientes nas plantas. In: FERREIRA, M.E.; CRUZ, M.C.P. (Ed.) Micronutrientes na agricultura. Piracicaba: POTAFOS, 1991. p.6578.
GUPTA, U.C. Boron nutrition of crops. Advances in Agronomy, v.31, p.273-307, 1979a.

GUPTA, U.C. Some factors affecting the determination of hot-water soluble boron from podzol soils using azomethine. Canadian Journal of Soil Science, v.59, p.241-247, 1979b.

GUPTA, U.C. Boron nutrition of alfalfa, red clover and timothy grown on Podzol soils of eastern Canada. Soil Science, v.137, p.16-22, 1984.

HADDAD, K.S.; KALDOR, C.J. Effect of parent material, natural available soil boron, and applied boron and lime on the growth and chemical composition of lucerne on some acidic soils of the central Tablelands of New South Wales. Australian Journal of Experimental Agriculture and Animal Husbandry, v.22, p.317-323, 1982.

HU, H.; BROWN, P.H. Absorption of boron by plants. Plant and Soil, v.193, p.49-58, 1997.

MARSCHNER, H. Mineral nutrition of higher plants. 2.ed. London: Academic Press, 1995. 889p.

MARTIN, W.E.; MATOCHA, J.E. Plant analysis as an aid in the fertilization of forage crops. In: WALSH, L.M.; BEATON, J.D. (Ed.) Soil testing and plant analysis. Madison: SSSA, 1973.

MELSTED, S.W.; MOTTO, H.L.; PECK, T.R. Critical plant nutrient composition values useful in interpreting plant analysis data. Agronomy Journal, v.61, p.17-20, 1969.

MENGEL, K.; KIRKBY, E. A. Principles of plant nutrition. 5.ed., Dordrecht: Kluwer Academic Publishers, 2001. 849p.

NUERNBERG, N.J. Técnicas de produção de alfafa. In: CONGRESSO BRASILEIRO DE PASTAGENS, 8., Piracicaba, 1986. Anais. Piracicaba: FEALQ, 1986. p.145-160.

OERTLI, J.J.; GRIGUREVIC, E. Effect of $\mathrm{pH}$ on the absorption of boron by excised barley roots. Agronomy Journal, v.67, p.278-280, 1975.

OTSUBO, A.A. Calagem e boro em um latossolo vermelho escuro cultivado com alfafa (Medicago sativa L.) Jaboticabal: UNESP/FCAV, 1993. 94p. (Dissertação- Mestrado).

ROMINGER, R.S.; SMITH, D.; PETERSON, L.A. Yields and elemental composition of alfalfa plant parts at late bud under two fertility levels. Canadian Journal of Plant Science, v.55, p.69-75, 1975.

SARRUGE, J.R. Soluções nutritivas. Summa Phytopathologica, v.1, p.231233, 1975.

SAS INSTITUTE. Property software Release 6.08. Cary: SAS Institute, 1989.

SHERREL, C.G.; TOXOPEUS, M.R.J. Effects of boron application on yield and boron concentration of alfalfa (Medicago sativa L.) grown on yellow-brown permice soils. New Zealand Journal of Experimental Agriculture, v.6, p.145-150, 1978.

SMITH, D. Yield and chemical composition of leaves and stems of alfalfa at intervals up the shoots. Journal of Agriculture and Food Chemistry, v.18, p.652-656, 1970.

Received August 08, 2003

Accepted July 14, 2004 